\title{
Antenatal risk factors for childhood diabetes mellitus; a case-control study of medical record data in Yorkshire, UK
}

\author{
P. A . M cK inney ${ }^{1}$, R . Parslow ${ }^{1}$, K . G urney ${ }^{1}$, G . L aw ${ }^{2}$, H .J . B odansky ${ }^{3}$, D.R . R . Williams ${ }^{4}$ \\ ${ }^{1}$ Paediatric Epidemiology Group, Centre for Health Services Research, University of Leeds, Leeds, UK \\ ${ }^{2}$ Leukaemia Research Fund Centre for Clinical Epidemiology, University of Leeds, Leeds, UK \\ ${ }^{3}$ The Diabetes Centre, Leeds General Infirmary, Great George Street, Leeds, UK \\ ${ }^{4}$ Division of Public Health, Nuffield Institute for Health, Leeds, UK
}

Summary Environmental risk factors for childhood insulin-dependent diabetes mellitus (IDDM) have been investigated using data abstracted from the obstetric records of mothers participating in a population-based case-control study of children ( $0-15$ years) diagnosed with IDDM during 1993-1994. A univariate analysis of 196 age and sex matched sets (129 triplets, 67 pairs) gave significantly raised odds ratios (OR) for mothers over 35 years (OR 2.13, $95 \%$ CI 1.04-4.36) and the following exposures in pregnancy: amniocentesis $(3.85,1.34-11.04)$, oedema, proteinuria and/or hypertensive disorders (1.62, 1.03-2.54), excessive weight gain $(7.12,1.50-33.79)$ and complications in labour $(1.49,1.00-2.21)$. The risk previously associated with caesarean deliveries was confirmed and the trend of increasing risk with age was significant. Adjusting separately for mothers with IDDM (4 cases, 0 control subjects), parity and small for gestational age failed to have any influence on the pregnancy risk factors or caesarean delivery. Case mothers undergoing amniocentesis were significantly younger compared to their control counterparts $(p=0.02)$ and the majority were given the test to determine fetal maturity, late in pregnancy, rather than to identify chromosomal abnormalities. Oedema, proteinuria and/or hypertension conferred an increased risk throughout pregnancy, particularly in the first two trimesters. No specific pattern of risk was present for any age group. Multivariate modelling of the significant OR, using conditional logistic regression, retained excessive weight gain as significant. The overall results present a risk profile of older mothers whose babies may be exposed to adverse intrauterine conditions and delivery by caesarean section. [Diabetologia (1997) 40: 933-939]

Keywords Childhood, insulin-dependent diabetes mellitus, epidemiology, case-control, obstetric risk factors, aetiology.
Childhood insulin-dependent diabetes mellitus (IDDM) is a chronic autoimmune condition resulting from selective 'self destruction' of pancreatic beta cells. The initiating factors involved in the pathogenic process remain to be clearly identified. Although underlying genetic susceptibility is necessary [1], it does not entirely account for disease occurrence. The

Received: 17 January 1997 and in revised form: 7 April 1997

Corresponding author: Dr. P. A. McKinney, Paediatric Epidemiology Group, Centre for Health Services Research, University of Leeds, 32 Hyde Terrace, Leeds LS2 9LN, UK

A bbreviations: IDDM, Insulin-dependent diabetes mellitus; $\mathrm{OR}$, odds ratio; CI, confidence interval. strength of the influence of environmental exposures is seen in studies of monozygotic twins where concordance for childhood IDDM is estimated to range from $13-53 \%$ [2-4]. Substantial variation in incidence rates internationally [5], within countries [6-8] and for migrant populations [9] remains to be explained.

Beta-cell destruction may begin many years prior to the onset of clinical symptoms in children with IDDM, so in utero and perinatal exposures to the developing fetus and neonate may be important determinants of disease. The role of viruses was suggested following the observation of increased risk of IDDM in congenital rubella syndrome [10] and congenital cytomegalovirus infection [11]. More recently, fetal exposure to enteroviruses has been associated with 
childhood IDDM [12]. Other maternal factors such as maternal-child blood group incompatibility [13], older age of mothers [13-17], toxaemia [13], maternal diabetes $[13,15]$ and mother's educational attainment $[14,15,18]$ appear to influence risk. Caesarean delivery $[13,15]$, birthweight $[19,20]$ and birth order $[15$, 16] have also been implicated, although the mechanisms are unclear. These factors were considered as a priori hypotheses alongside additional new variables being examined for evidence of association.

The current analytical epidemiological investigation has examined a range of obstetric factors in relation to the development of IDDM in children. The source of data were obstetric hospital records of mothers interviewed for a case-control study of IDDM in children, conducted in the northern English county of Yorkshire.

\section{Subjects, materials and methods}

The methodology conforms to that of a standard population based case-control study [21]. Ethical approval was given by all the relevant local research ethics committees.

Cases. From 1978, the Yorkshire Childhood Diabetes Register has recorded cases of children (under 16 years) diagnosed with IDDM while resident within the geographical area of the former Yorkshire Regional Health Authority. The register ascertains children from three independent sources and is estimated to be $97 \%$ complete [22]. For the years 1993 and 1994, all children aged 0-15 were eligible for the study, excluding those resident in the District Health Authority areas of Grimsby, Scunthorpe and Cleethorpes. Permission was sought from treating hospital clinicians to approach parents and request their participation.

Control subjects. The Family Health Service Authority (FHSA) of the index case was the sampling frame for selecting population based controls, matched on age (within 1 month) and sex. Two randomly selected general practioners (GP), from the FHSA, each provided details of four mothers and their children, along with permission to approach. A mother from each GP was interviewed and refusals were replaced to provide two controls per case.

$D$ ata collection. Mothers of cases and control subjects were approached by letter and asked to participate. A face-to-face interview using a standard form gathered demographic, social and lifestyle data including details of the index child's place of birth. Social class was assigned based on mothers' occupation at the time of interview using the Registrar General Standard scheme [23]. Ethnic group and marital status were categorised according to the UK decennial census.

Signed consent was obtained for abstraction of the mother's obstetric notes. A structured standard form designed and validated at the Imperial Cancer Research Fund Epidemiology Unit, Oxford, UK [24] was completed for all the notes by a single trained research midwife, who was blind to case-control status. Information collected included the first antenatal visit, illnesses and operations in pregnancy, drugs in pregnancy, ultrasound scans, X rays, blood tests, labour record and delivery details. Information on parity was derived from mothers' reports and small for gestational age defined according to recent UK birth data taking 2 standard deviations below the mean
Table 1. Frequency of case and control subjects' eligibility and levels of participation

\begin{tabular}{|c|c|c|c|c|}
\hline Interviews & $\begin{array}{l}\text { Cases } \\
\mathrm{n}\end{array}$ & $\%$ & $\begin{array}{l}\text { Control } \\
\text { subjects } n\end{array}$ & $\%$ \\
\hline Interviewed & 220 & 93.6 & 433 & 81.9 \\
\hline Refusals $^{\mathrm{a}}$ & 15 & 6.4 & 96 & 18.1 \\
\hline Total & 235 & & 529 & \\
\hline \multicolumn{5}{|l|}{ R efusals } \\
\hline Consultant/GP & 2 & 13.3 & 1 & 1.0 \\
\hline Parental & 13 & 86.6 & 95 & 99.0 \\
\hline Total & 15 & & 96 & \\
\hline \multicolumn{5}{|l|}{ Ineligibles } \\
\hline Child adopted & 3 & 23.1 & 1 & 2.5 \\
\hline Child fostered/in care & 1 & 7.7 & 0 & \\
\hline Language difficulties & 2 & 15.4 & 6 & 15.0 \\
\hline Not traceable & 4 & 30.8 & 23 & 57.5 \\
\hline Out of time & 0 & & 7 & 17.5 \\
\hline Other & 3 & 23.1 & 3 & 7.5 \\
\hline Total & 13 & & 40 & \\
\hline \multicolumn{5}{|l|}{ O bstetric records } \\
\hline Notes abstracted & 202 & 91.8 & 354 & 81.8 \\
\hline Interviewed only & 18 & 8.2 & 79 & 18.2 \\
\hline Total & 220 & & 433 & \\
\hline \multicolumn{5}{|l|}{ R easons for non-abstraction } \\
\hline Location of birth untraced & 0 & - & 5 & 0.4 \\
\hline No maternal consent & 1 & 5.6 & 5 & 0.4 \\
\hline Notes untraced & 17 & 94.4 & 57 & 72.1 \\
\hline Not sought & 0 & - & 12 & 15.2 \\
\hline Total & 18 & & 79 & \\
\hline
\end{tabular}

a Two cases were siblings of previously interviewed cases and for the remainder the mothers had died

birthweight for gestational week [25]. No babies were large for gestational age. Illnesses during pregnancy and complications in labour were coded using the International Classification of Diseases version 10 [26] and drugs in pregnancy used the framework of the prescription manual the British National Formulary [27]. Illnesses and drugs were grouped a priori into categories of specific interest and with sufficient numbers for analysis, for example, infections and anti-infective agents. Details of groups and their corresponding codes are available from the authors.

Medical records were obtained from 17 maternity hospitals in Yorkshire but $12.9 \%$ of births were elsewhere in the UK and abroad and records were requested by post for abstraction.

Participation. Over the 2-year study period 248 children with IDDM were registered of whom 220 were interviewed, 13 were ineligible and 15 refused. Details of the case and control participation rates in the main interview study are given in Table 1 in relation to the proportion of mothers whose obstetric notes were abstracted: $78 \%$ of controls were first choice and $18 \%$ second choice. Data available for analysis comprised 129 matched triplets and 67 matched pairs giving 196 matched sets, totalling $89.1 \%$ of interviewed cases. The remaining 6 cases and 29 control subjects had no respective match and were excluded from the analysis.

Statistical analysis. Data from matched case-control pairs and triplets were analysed using Stata [28] which allows for variable matching ratios of cases to controls. Conditional logistic regression was used to estimate the Odds Ratios (OR) with exact $95 \%$ Confidence Intervals $(\mathrm{CI})$, and 2 sided $p$ values for univariate point estimates and multivariate modelling.

With approximately 200 matched sets, the study has $80 \%$ power to detect a relative risk of 2 to 2.5 at a $5 \%$ level of 
Table 2. Demographic profile of cases $(n=196)$ and matched control subjects $(\mathrm{n}=325)$

\begin{tabular}{|c|c|c|c|c|}
\hline Factor & $\begin{array}{l}\text { Cases } \\
\mathrm{n}\end{array}$ & $\%^{a}$ & $\begin{array}{l}\text { Control } \\
\text { subjects } n\end{array}$ & $\%^{a}$ \\
\hline \multicolumn{5}{|l|}{ E ducational qualifications } \\
\hline None & 70 & 35.7 & 101 & 31.1 \\
\hline Basic & 68 & 34.7 & 118 & 36.3 \\
\hline Higher & 58 & 29.6 & 106 & 32.6 \\
\hline \multicolumn{5}{|l|}{ M other's school leaving age } \\
\hline 15 years and under & 50 & 25.5 & 69 & 21.2 \\
\hline 16 years & 98 & 50.0 & 156 & 48.0 \\
\hline over 16 years & 44 & 22.4 & 97 & 29.8 \\
\hline not known & 4 & 2.0 & 3 & 0.9 \\
\hline \multicolumn{5}{|l|}{ E thnic group } \\
\hline Black (Caribbean and other) & 1 & 0.5 & 2 & 0.6 \\
\hline Indian/Pakistani & 8 & 4.1 & 10 & 3.1 \\
\hline White & 186 & 94.9 & 311 & 95.7 \\
\hline Other & 1 & 0.5 & 2 & 0.6 \\
\hline \multicolumn{5}{|l|}{ M arital Status } \\
\hline Married & 151 & 77.0 & 263 & 80.9 \\
\hline Cohabiting & 16 & 8.2 & 24 & 7.4 \\
\hline Divorced & 13 & 6.4 & 19 & 5.8 \\
\hline Separated & 8 & 4.1 & 10 & 3.1 \\
\hline Single & 8 & 4.1 & 9 & 2.8 \\
\hline \multicolumn{5}{|l|}{ Social Class } \\
\hline Professional & 2 & 1.0 & 8 & 2.5 \\
\hline Managerial & 45 & 23.0 & 61 & 18.8 \\
\hline Skilled non-manual & 36 & 18.4 & 69 & 21.2 \\
\hline Skilled manual & 8 & 4.1 & 24 & 7.4 \\
\hline Partly skilled & 28 & 14.3 & 50 & 15.4 \\
\hline Unskilled & 4 & 2.0 & 15 & 4.6 \\
\hline Not classified & 73 & 37.2 & 98 & 30.2 \\
\hline
\end{tabular}

${ }^{a}$ Percentage of total numbers

significance if the factor under investigation is prevalent in $10 \%$ of the control population [21].

\section{Results}

A demographic profile of all the mothers whose notes had been abstracted was taken from reported details on the interview forms (Table 2). Case mothers tended to be more poorly educated, leaving school at an earlier age although these differences were not significant (Table 3). Marital status exhibited no case-control differences. Cases and controls were not matched by ethnic group but the distributions between them were similar. Social class displayed a similar overall profile for cases and control subjects but there was a notable excess of case mothers who were not in paid work at the time of interview and remained unclassified. Ethnic group, marital status and social class were excluded from further analyses.

For all matched pairs and triplets $(n=196)$ odds ratios (OR) for each variable are given in Table 3 with accompanying $95 \% \mathrm{CI}$ and levels of significance. The results show increasing risk associated with mother's age (chi square test for trend $p<0.001$ ), with a twofold excess for mothers over
35 years. There were four mothers of case children and none of the control subjects who had a diagnosis of IDDM prior to pregnancy. Oedema, proteinuria and/or hypertensive disorders of pregnancy (pre-eclampsia) were associated with an increased risk at each trimester of pregnancy. The OR of 7.12 for excessive weight gain was accounted for by weight gain in the third trimester. Prescription of analgesics carried a twofold but non-significant risk as did antihypertensive drugs. Complications in labour conferred a raised OR of 1.5. However, examination of individual codes failed to demonstrate any link with a specific complication. For drugs taken during labour hypnotics and anxiolytics (benzodiazepines) were of borderline significance.

Caesarean section compared to normal spontaneous deliveries was significant but adjusting for the mothers with pre-existing IDDM, on the grounds that they were more likely to have undergone the procedure because of their condition, slightly reduced the level of risk (OR 1.73, 95\% CI.1.02-2.94). Links with emergency procedures almost reach significance compared to a non-significant OR for planned operations. There was no case excess of fetal distress or intrauterine growth problems amongst the caesarean deliveries. For three case and no control mothers a caesarean section was performed for a multiple pregnancy. The OR for preterm births, first pregnancy and babies defined as small for gestational age were not significant.

To investigate potential age effects the significant univariate risks were analysed by age bands at diagnosis, 0-4 (cases $n=40), 5-9($ cases $n=81), 10-15$ (cases $n=75$ ). The results did not show any systematic effect for any age group, although the power to detect risks by subgroup was reduced by the small numbers.

All the univariate OR significant at the $5 \%$ level [age of mother (2 groups: $25-35,>35$ ), amniocentesis, IDDM in mothers, pre-eclamptic conditions, excessive weight gain, complications in labour and caesarean delivery] were adjusted separately for mothers with IDDM, parity and small for gestational age babies; overall, there was little effect. Statistical significance of the risk for labour complications was removed by adjusting for IDDM mothers. Adjustment for first pregnancy gave marginal significance to the OR for mothers aged 25-35.

Conditional logistic regression was applied to potential explanatory variables retaining significance after adjustment, that is mothers' age, amniocentesis, hypertension and pre-eclampsia, excessive weight gain and caesarian delivery. The multivariate modelling only retained excessive weight gain as significant. The fit of the model was chi square $=30.07$. $7 \mathrm{df}, \mathrm{p}<0.001$. No other single risk factor emerged as significant from alternative models.

Amniocentesis had a highly significant threefold risk. Details of the 13 case and 9 control mothers in 
Table 3. Univariate odds ratio for obstetric risk factors

\begin{tabular}{|c|c|c|c|c|c|c|}
\hline \multirow[t]{2}{*}{ Factor } & \multirow[t]{2}{*}{ Category } & \multicolumn{2}{|c|}{ Number (\%) of subjects } & \multirow[t]{2}{*}{$\mathrm{OR}^{\mathrm{a}}$} & \multicolumn{2}{|c|}{$95 \% \mathrm{CI}$} \\
\hline & & $\begin{array}{l}\text { Cases } \\
\mathrm{n}=196\end{array}$ & $\begin{array}{l}\text { Control subjects } \\
\mathrm{n}=325\end{array}$ & & & \\
\hline Mother's school leaving age & $>16$ years & $44(22.9)$ & $97(30.1)$ & 0.67 & 0.43 & 1.04 \\
\hline Mothers age at index birth & $\begin{array}{l}<25 \text { years }^{\mathrm{b}} \\
25-35 \text { years } \\
>35 \text { years }\end{array}$ & $\begin{array}{r}53(27.0) \\
123(62.8) \\
20(10.2)\end{array}$ & $\begin{aligned} & 121(37.2) \\
& 182(56.0) \\
& 22(6.8)\end{aligned}$ & $\begin{array}{l}1.00 \\
1.53^{\mathrm{e}} \\
2.13^{\mathrm{e}}\end{array}$ & $\begin{array}{l}1.02 \\
1.04\end{array}$ & $\begin{array}{l}2.29 \\
4.36\end{array}$ \\
\hline Antenatal care & $\begin{array}{l}\text { GP + hospital } \\
\text { hospital only } \\
\text { GP only }\end{array}$ & $\begin{array}{c}173(90.1) \\
16(8.3) \\
3(1.6)\end{array}$ & $\begin{aligned} 284 & (93.1) \\
14 & (4.6) \\
7 & (2.3)\end{aligned}$ & $\begin{array}{l}1.00 \\
1.70 \\
0.78\end{array}$ & $\begin{array}{l}0.79 \\
0.19\end{array}$ & $\begin{array}{l}3.68 \\
3.22\end{array}$ \\
\hline $\mathrm{X}$-rays in utero & 1 or more & $19(5.9)$ & $19(9.7)$ & 1.66 & 0.85 & 3.23 \\
\hline Ultrasound scans & 1 or more & $171(87.2)$ & $281(86.5)$ & 1.11 & 0.64 & 1.93 \\
\hline Amniocentesis & 1 or more & $13(6.6)$ & $6(1.9)$ & $3.85^{\mathrm{f}}$ & 1.34 & 11.04 \\
\hline Mother's blood group & $\begin{array}{l}\text { group } \mathrm{O}^{\mathrm{b}} \\
\text { group } \mathrm{A} \\
\text { group } \mathrm{B} \\
\text { group } \mathrm{AB}\end{array}$ & $\begin{array}{l}81(42.9) \\
82(43.4) \\
16(8.5) \\
10(5.3)\end{array}$ & $\begin{array}{c}150(47.9) \\
126(40.3) \\
23(7.4) \\
14(4.5)\end{array}$ & $\begin{array}{l}1.00 \\
1.20 \\
1.16 \\
1.38\end{array}$ & $\begin{array}{l}0.82 \\
0.58 \\
0.56\end{array}$ & $\begin{array}{l}1.76 \\
2.34 \\
3.38\end{array}$ \\
\hline Illnesses in pregnancy & $\begin{array}{l}\text { Infections } \\
\text { Endocrine disorders } \\
\text { Pre-existing IDDM } \\
\text { Gestational diabetes } \\
\text { Epilepsy } \\
\text { Hypertension and pre-eclampsia } \\
\text { Early haemorrhage } \\
\text { Maternal care for fetal problems } \\
\text { Nausea and vomiting } \\
\text { Excessive weight gain } \\
\text { Low weight gain }\end{array}$ & $\begin{aligned} 29 & (14.8) \\
2 & (1.0) \\
4 & (2.0) \\
3 & (1.5) \\
1 & (0.5) \\
44 & (22.5) \\
10 & (5.1) \\
15 & (7.7) \\
1 & (0.5) \\
8 & (4.1) \\
9 & (4.6)\end{aligned}$ & $\begin{aligned} & 49(15.1) \\
& 1(0.3) \\
& 0(0.0) \\
& 2(0.6) \\
& 4(1.2) \\
& 49(15.1) \\
& 11(3.4) \\
& 22(6.8) \\
& 7(2.2) \\
& 2(0.6) \\
& 10(3.1)\end{aligned}$ & $\begin{array}{l}1.06 \\
4 \\
\infty \\
\\
0.32 \\
1.62^{\mathrm{e}} \\
1.6 \\
1.31 \\
0.26 \\
7.12^{\mathrm{f}} \\
1.65\end{array}$ & $\begin{array}{l}0.35 \\
1.03 \\
0.65 \\
0.62 \\
0.03 \\
1.50 \\
0.62\end{array}$ & $\begin{array}{r}2.90 \\
2.54 \\
4.00 \\
2.74 \\
2.10 \\
33.79 \\
4.39\end{array}$ \\
\hline $\begin{array}{l}\text { Hypertension and } \\
\text { pre-eclampsia by trimester }\end{array}$ & $\begin{array}{l}\text { Trimester } 1 \\
\text { Trimester } 2 \\
\text { Trimester } 3\end{array}$ & $\begin{array}{c}8(4.1) \\
8(4.1) \\
43(21.9)\end{array}$ & $\begin{array}{c}2(0.6) \\
3(0.9) \\
49(15.1)\end{array}$ & $\begin{array}{l}6.27^{\mathrm{e}} \\
4.00^{\mathrm{e}} \\
1.57^{\mathrm{e}}\end{array}$ & $\begin{array}{l}1.32 \\
1.05 \\
1.00\end{array}$ & $\begin{array}{r}29.93 \\
15.31 \\
2.47\end{array}$ \\
\hline Drugs in pregnancy & $\begin{array}{l}\text { Analgesics } \\
\text { Antacids } \\
\text { Asthma } \\
\text { Antiepileptics } \\
\text { Antihypertensives } \\
\text { Antibacterial } \\
\text { Antifungals } \\
\text { Antiinfectives } \\
\text { Antinauseants } \\
\text { Hypnotics/anxiolytics } \\
\text { Vaccines } \\
\text { Vitamins }\end{array}$ & $\begin{aligned} & 16(8.2) \\
& 10(5.1) \\
& 3(1.5) \\
& 1(0.5) \\
& 5(2.6) \\
& 18(9.2) \\
& 16(8.2) \\
& 29(14.8) \\
& 9(4.6) \\
& 13(6.6) \\
& 3(1.5) \\
& 82(41.8)\end{aligned}$ & $\begin{array}{r}14(4.3) \\
15(4.6) \\
6(1.9) \\
4(1.2) \\
3(0.9) \\
26(8.0) \\
20(6.2) \\
45(13.9) \\
12(3.7) \\
21(6.5) \\
2(0.6) \\
133(40.9)\end{array}$ & $\begin{array}{l}2.07 \\
1.10 \\
0.78 \\
0.32 \\
2.84 \\
1.26 \\
1.38 \\
1.16 \\
1.24 \\
1.15 \\
2.30 \\
1.06\end{array}$ & $\begin{array}{l}0.97 \\
0.47 \\
0.19 \\
0.04 \\
0.67 \\
0.67 \\
0.70 \\
0.70 \\
0.50 \\
0.56 \\
0.38 \\
0.72\end{array}$ & $\begin{array}{r}4.44 \\
2.56 \\
3.18 \\
2.90 \\
12.05 \\
2.38 \\
2.71 \\
1.94 \\
3.04 \\
2.35 \\
14.12 \\
1.55\end{array}$ \\
\hline Type of labour & $\begin{array}{l}\text { Spontaneous } \\
\text { Prostaglandin assisted } \\
\text { Artificial rupture of membranes } \\
\text { Oxytoxic infusion }\end{array}$ & $\begin{array}{r}136(69.4) \\
25(12.8) \\
113(57.7) \\
54(27.6)\end{array}$ & $\begin{array}{r}234(72.0) \\
39(12.0) \\
183(56.3) \\
91(28.0)\end{array}$ & $\begin{array}{l}0.89 \\
1.03 \\
1.06 \\
0.96\end{array}$ & $\begin{array}{l}0.59 \\
0.58 \\
0.73 \\
0.64\end{array}$ & $\begin{array}{l}1.35 \\
1.83 \\
1.52 \\
1.43\end{array}$ \\
\hline Complication in labour & 1 or more & $63(32.1)$ & $77(23.7)$ & $1.49^{\mathrm{e}}$ & 1.00 & 2.21 \\
\hline Drugs in labour & $\begin{array}{l}\text { Antacids } \\
\text { Anaesthetics } \\
\text { Antihistamines } \\
\text { Hypnotics/anxiolytics } \\
\text { Tranquilisers } \\
\text { Antinauseants } \\
\text { Analgesics } \\
\text { Antibacterials }\end{array}$ & $\begin{aligned} & 61(31.1) \\
& 126(64.3) \\
& 26(13.3) \\
& 8(4.1) \\
& 26(13.3) \\
& 13(6.6) \\
& 100(51.0) \\
& 3(1.5)\end{aligned}$ & $\begin{aligned} 92 & (28.3) \\
182 & (56.0) \\
36 & (11.1) \\
5 & (1.5) \\
53 & (16.3) \\
30 & (9.2) \\
164 & (50.5) \\
4 & (1.2)\end{aligned}$ & $\begin{array}{l}1.18 \\
1.42 \\
1.27 \\
3.05 \\
0.79 \\
0.55 \\
1.03 \\
1.36\end{array}$ & $\begin{array}{l}0.79 \\
0.98 \\
0.74 \\
0.99 \\
0.46 \\
0.24 \\
0.72 \\
0.30\end{array}$ & $\begin{array}{l}1.78 \\
2.07 \\
2.19 \\
9.36 \\
1.37 \\
1.28 \\
1.46 \\
6.13\end{array}$ \\
\hline Type of delivery & $\begin{array}{l}\text { Normal } \\
\text { Assisted } \\
\text { Caesarian }\end{array}$ & $\begin{array}{r}140(71.4) \\
22(11.2) \\
34(17.4)\end{array}$ & $\begin{array}{r}255(78.5) \\
35(10.8) \\
35(10.8)\end{array}$ & $\begin{array}{l}1.00 \\
1.17 \\
1.84^{\mathrm{e}}\end{array}$ & $\begin{array}{l}0.66 \\
1.09\end{array}$ & $\begin{array}{l}2.08 \\
3.10\end{array}$ \\
\hline Reason for caesarian ${ }^{\mathrm{g}}$ & $\begin{array}{l}\text { Emergency } \\
\text { Planned }\end{array}$ & $\begin{array}{l}18(9.2) \\
16(8.2)\end{array}$ & $\begin{array}{l}20(6.2) \\
15(4.6)\end{array}$ & $\begin{array}{l}1.97 \\
1.81\end{array}$ & $\begin{array}{l}0.98 \\
0.84\end{array}$ & $\begin{array}{l}3.94 \\
3.92\end{array}$ \\
\hline Placental abnormalities & 1 or more & $47(24.0)$ & $72(22.2)$ & 1.05 & 0.69 & 1.62 \\
\hline Gestation at birth & 37 weeks or less & $24(12.2)$ & $35(10.8)$ & 1.21 & 0.69 & 2.10 \\
\hline Small for gestational age & Yes & $6(3.1)$ & $7(2.2)$ & 1.63 & 0.54 & 4.86 \\
\hline Parity & First pregnancy & $61(31.1)$ & $115(35.4)$ & 0.82 & 0.56 & 1.19 \\
\hline
\end{tabular}

a OR calculated from informative matched sets;

${ }^{\mathrm{b}}$ reference group;

$\mathrm{c}$ independent categories with positive exposure including one or more episodes; $\mathrm{d}$ reference group of no episode within trimester;

e significant $p<0.05$

${ }^{\mathrm{f}}$ significant $\mathrm{p}<0.001$;

$\mathrm{g}$ reference group of normal delivery 
Table 4. Profile of case and control mothers who underwent amniocentesis

\begin{tabular}{|c|c|c|c|c|}
\hline & $\begin{array}{l}\text { Year } \\
\text { of } \\
\text { birth }\end{array}$ & $\begin{array}{l}\text { Mothers } \\
\text { age } \\
\text { (years) }\end{array}$ & $\begin{array}{l}\text { Gestation } \\
\text { at amnio- } \\
\text { centesis }\end{array}$ & $\begin{array}{l}\text { Reason for } \\
\text { amniocentesis }^{\mathrm{a}}\end{array}$ \\
\hline \multirow{13}{*}{ Cases } & 1989 & 29 & not known & maternal request \\
\hline & 1988 & 42 & 15 & elderly primipara \\
\hline & 1985 & 38 & 16 & maternal age \\
\hline & 1986 & 27 & 16 & $\begin{array}{l}\text { increased alpha } \\
\text { fetoprotein }\end{array}$ \\
\hline & 1986 & 27 & 17 & $\begin{array}{l}\text { sister's child with } \\
\text { neuroblastoma }\end{array}$ \\
\hline & 1981 & 40 & 17 & not known \\
\hline & 1984 & 38 & 19 & not known \\
\hline & 1983 & 25 & 30 & twin pregnancy \\
\hline & 1980 & 28 & 37 & $\begin{array}{l}\text { previous anence- } \\
\text { phalic death }\end{array}$ \\
\hline & 1979 & 25 & 37 & $\mathrm{~L} / \mathrm{S}^{\mathrm{b}}$ ratio \\
\hline & 1978 & 35 & 37 & $\begin{array}{l}\text { suspected intra- } \\
\text { uterine growth } \\
\text { retardation }\end{array}$ \\
\hline & 1979 & 43 & 38 & $\begin{array}{l}\text { low risk respiratory } \\
\text { distress syndrome } \\
\text { prior to elective } \\
\text { caesarian }\end{array}$ \\
\hline & 1979 & 26 & 40 & $\mathrm{~L} / \mathrm{S}^{\mathrm{b}}$ ratio \\
\hline Mean & 1983 & $32^{\mathrm{c}}$ & 26 & \\
\hline Control & 1985 & 39 & 11 & not known \\
\hline \multirow[t]{8}{*}{ subjects } & 1992 & 42 & 13 & maternal age \\
\hline & 1988 & 35 & 14 & elderly primipara \\
\hline & 1979 & 36 & 16 & $\begin{array}{l}\text { previous neonatal } \\
\text { death }\end{array}$ \\
\hline & 1983 & 37 & 16 & not known \\
\hline & 1978 & 37 & 16 & not known \\
\hline & 1984 & 44 & 17 & elderly gravida 5 \\
\hline & 1983 & 36 & 19 & $\begin{array}{l}\text { fragment } F \text { in mater- } \\
\text { nal blood }\end{array}$ \\
\hline & 1980 & 43 & 29 & $\begin{array}{l}\text { fetal maturity prior } \\
\text { to elective caesarian, } \\
\text { Rh incompatibility }\end{array}$ \\
\hline Mean & & $39^{c}$ & 17 & \\
\hline
\end{tabular}

a Reason recorded in medical notes;

${ }^{\mathrm{b}} \mathrm{L} / \mathrm{S}$ ratio, lecithin/sphingomyelin ratio, to test for fetal maturity;

${ }^{c}$ significantly different ( $t$ test, $t=2.81,20 d f, p=0.02$ )

Table 4, clearly shows a different pattern of exposure. The control mothers displayed an expected distribution for the procedure, that is, being administered in the second trimester of pregnancy to ascertain chromosomal abnormalities in the fetus of older mothers. However, the case mothers undergoing amniocentesis were significantly younger ( $t$-test, $t=2.81,20 \mathrm{df}$, $p=0.02$ ) and the amniocentesis was used as a diagnostic test for fetal maturity in late pregnancy, mainly from births in the late 1970 s and early $1980 \mathrm{~s}$.

\section{Discussion}

Case-control studies investigating risks for childhood IDDM associated with in utero exposures have been conducted using reported information from mothers $[14,16,19]$ or national datasets of variables routinely collected for descriptive statistics $[13,15,29]$. We report the results of the first large scale populationbased case-control study analysing detailed data directly abstracted from hospital medical records, permitting investigation of an extensive range of variables not available from birth statistics [13, 15, 29]. The effects of a number of putative risk factors not previously examined are reported.

High quality population-based disease registers underpin both descriptive and analytical epidemiological studies and for the current investigation the Yorkshire Childhood Diabetes Register, established as $97 \%$ complete, provided the framework for ascertaining cases [22]. Interview information from casecontrol studies is vulnerable to bias particularly that introduced by interviewers and mother's recall. Careful training of interviewers and use of a highly structured and validated questionnaire aimed to reduce any effect. Possible risk factors for IDDM are not widely known and mothers of cases are unlikely to over-report on items included in this analysis. In contrast, the obstetric record abstractions provide an unbiased source of information, recorded by a single research midwife who was unaware of case-control status. A high proportion of interviewed case and control mothers had their hospital obstetric records abstracted but no evidence existed to suggest any temporal or geographical case-control bias for the unobtainable notes. The quality of the obstetric notes was generally very good, successfully providing a high quality historical data set spanning 20 years.

The finding of increased risk with maternal age confirms observations from other studies [13-18] and is therefore likely to represent a real association. Social class groupings according to mothers' occupations at the time of interview, therefore post-diagnosis, were not dissimilar for cases and control subjects but there was a notable excess of case mothers unclassified because they were not in paid employment. Mothers of children with IDDM are possibly less likely to be working, due to the demands of caring for a child with a chronic disease. Social class proxies, mother's school leaving age and level of education, showed case mothers left school earlier and were less well qualified than their comparison controls although the differences were not significant. Some studies $[14,15,18]$ but not all [15] have observed low socio-economic class linked to an increased risk. Results from ecological studies are inconsistent with these findings, where living in densely populated areas and overcrowded houses reduces risk [30, 31]. These apparently incompatible observations are likely to reflect different methodological approaches, with case-control studies tending to suffer from higher participation rates of control subjects in higher social groups. Stringent efforts were made in the 
Yorkshire study to reduce this selection bias by assiduously following up all the randomly selected controls and a high proportion (78\%) were first choice.

The current study and others $[14,15,18]$ failed to find an association with length of gestation in contrast to a Scandavian study [13]. An indicator of fetal development is 'birthweight by gestational age' and 'small for gestational age' babies appear to be at reduced risk from childhood IDDM [29], although this was not observed in our analysis.

Mothers with IDDM would be expected to confer a risk to their offspring by transmitting genetic susceptibility and the current study and others $[12,15]$ confirm this. An increased risk for 'oedema, proteinuria and hypertension' has been observed in Scandanavia [14] but not in Scotland or Northern Ireland [15]. Any detrimental effect on the fetus from hypertension or disturbed metabolism associated with pre-eclampsia is likely to be strongest in the early stages of fetal development and a novel finding in the Yorkshire study associated particularly high risk with the first two trimesters of pregnancy. Excessive weight gain in pregnancy, the most statistically significant finding, is clinically closely linked to symptoms of toxaemia.

The threefold risk of amniocentesis, not accounted for by mothers with IDDM, is a new finding and requires independent confirmation in other studies. The profiles of cases and control subjects revealed very different patterns, with the procedure undertaken later and in younger case mothers for detecting fetal problems, such as suspected intrauterine growth retardation or maturation. Our findings weakly point towards poor fetal development being associated with increased risk, an observation inconsistent with a recent study [29] showing a decreased risk for babies defined as small for gestational age.

The mechanism by which intrauterine growth retardation and the effects of maternal hypertension might directly affect development of the pancreas can be inferred, somewhat speculatively, from work demonstrating the occurrence of compensatory redistribution of blood flow and blood oxygen content, to favour vital organs such as the brain, thus reducing the supply to abdominal organs [32]. These circumstances might conceivably influence the development of beta-cell mass and/or differentiation providing a susceptible target for the destructive autoimmune process.

Drugs taken in pregnancy have not been previously examined in such detail in relation to the risk of IDDM and nothing of interest emerged from the current analysis. No evidence was found for any risk of infections in pregnancy or the prescription of antiinfective drugs. The ideal approach to evaluating risk of infections are serological studies, such as those implicating coxsackie viruses [12].

Caesarean section has now been confirmed as conferring risk in a number of studies, although the mechanism by which this has a biological effect is not obvious. Risks for emergency caesarians, amniocentesis, toxaemia and excess weight gain are suggestive of pregnancies where concern for fetal viability might exist, making surgical intervention more likely.

In summary, this study reports new risk factors for childhood IDDM associated with amniocentesis and excessive weight gain, while confirming previous observations of raised risk for caesarean deliveries and toxaemia. The possibility of the intrauterine environment affecting future risk requires further study of the potential underlying mechanisms.

A cknowledgements. This work has been financially supported by grants from The British Diabetic Association, the Children's Research Fund, Novo Nordisk and The Special Trustees of the General Infirmary, Leeds. Dr Eve Roman is thanked for permission to use the validated data collection instrument. We are indebted to the Carolyn Stephenson, Elaine Longshaw, Heather Walker, Janet Amos, Marcia Ledgard and Helen Breton for data collection. Sheila Jones is thanked for her contribution to data processing and typing the manuscript. All the Paediatricians, Physicians and General Practitioners in Yorkshire are thanked for their collaboration and we are grateful for the continued support of all the Diabetes Specialist Nurses. The study data will contribute to EURODIAB sub study 2 investigating environmental risk factors for childhood IDDM.

\section{References}

1. Davies JL, Kawaguchi Y, Bennett ST et al. (1994) A genome wide search for human type 1 diabetes susceptibility genes. Nature 371: 130-136

2. Kaprio J, Tuomilehto J, Koskenvuo et al. (1992) Concordance for type 1 (insulin dependent) and type 2 (non-insulin dependent) diabetes mellitus in a population-based cohort of twins in Finland. Diabetologia 35: 1060-1067

3. Leslie RDG (1993) Diabetic twin studies. In: RDG Leslie (ed) Causes of diabetes. John Wiley and Son, Chichester, New York, Brisbane, Toronto, Singapore

4. Kyvik KO, Green A, Beck-Nielsen H (1995) Concordance rates of insulin dependent diabetes mellitus: a population based study of young Danish twins. BMJ 311: 913-917

5. Green A, Gale EAM, Patterson CC (1992) Incidence of childhood-onset insulin dependent diabetes mellitus: The EURODIAB ACE study. The Lancet 339: 905-909

6. McKinney PA, Law GR, Bodansky HJ, Staines A, Williams DRR (1996) Geographical mapping of childhood diabetes in the Northern English county of Yorkshire. Diabet Med 13: 734-740

7. Patterson CC, Waugh NR (1992) Urban/rural and deprivational differences in incidence and clustering of childhood diabetes in Scotland. Int J Epidemiol 21: 108-117

8. Colle E, Siemiatycki J, West R, Belmonte MM, Crepeau MP, Poirer R, Wilkins J (1981) Incidence of juvenile onset diabetes in Montreal - demonstration of ethnic differences and socio-economic class differences. J Chron Dis 34: 611-616

9. Bodansky HJ, Staines A, Stephenson C, Haigh D, Cartwright RA (1992) Evidence for an environmental effect in the aetiology of insulin dependent diabetes in a transmigratory population. BMJ 304: 1020-1022

10. Menser MA, Forrest JM, Bransby RD (1978) Rubella infection and diabetes mellitus. Lancet 1: 57-60 
11. Ward KP, Galloway WH, Auchterlonie JA (1979) Congenital cytomegalovirus infection and diabetes. Lancet 1: 497

12. Dahlquist G, Frisk G, Ivarsson SA, Svanberg L, Forsgren M, Diderholm H (1995) Indications that maternal coxsackie $B$ virus infection during pregnancy is a risk factor for childhood IDDM. Diabetologia 38: 1371-1373

13. Dahlquist G, Kallen B (1992) Maternal-child blood group incompatibility and other perinatal events increase the risk for early onset type 1 (insulin-dependent) diabetes mellitus. Diabetologia 53: 671-675

14. Blom L, Dahquist GG, Nystrom L, Sandstrom A, Wall S (1989) The Swedish childhood diabetes study - social and perinatal determinants for diabetes in childhood. Diabetologia 32: 7-13

15. Patterson CC, Waugh NR, Carson DJ, Cole SK, Hadden DR (1994) A case-control investigation of perinatal risk factors for childhood IDDM in Northern Ireland and Scotland. Diabetes Care 17: 376-381

16. Wagener DK, LaPorte RE, Orchard TJ, Cavender D, Kuller LH, Drash AL (1983) The Pittsburgh Diabetes Mellitus Study 3: An increased prevalence with older maternal age. Diabetologia 25: 82-85

17. Flood TM, Brink SJ, Gleason RE (1982) Increased incidence of type 1 diabetes in children of older mothers. Diabetes Care 5: 571-573

18. Soltesz G, Jeges S, Dahquist G and the Hungarian Diabetes Epidemiology Study Group (1994) Non-genetic determinants for type 1 (insulin dependent) diabetes mellitus in childhood. Acta Paediatr 83: 730-735

19. Lawler-Heavner J, Cruikshank KJ, Hay WW, Gay EC, Hamman RF (1994) Birth size and risk of insulin dependent diabetes mellitus (IDDM). Diabetes Res Clin Pract 24: 153-159

20. Metcalf MA, Baum JD (1992) Family characteristics and insulin dependent diabetes. Arch Dis Child 67: 731-736

21. Breslow NE, Day NE (1980) Statistical methods in cancer research: vol. 1 The analysis of case-control studies. IARC Scientific Publications, no 32 Lyon
22. Staines A, Bodansky HJ, Lilley HEB et al. (1993) The epidemiology of diabetes mellitus in the United Kingdom: The Yorkshire Regional Childhood Diabetes Register. Diabetologia 36: 1282-1287

23. Standard Occupational Classification volume 3 (1991) Office of Population Censuses and Surveys. London HMSO

24. Ansell P, Bull D, Roman E (1996) Childhood leukaemia and intramuscular vitamin $\mathrm{K}$ : findings from a case-control study. BMJ 313: 204-205

25. Wilcox M, Gardosi J, Mongelli M, Ray C, Johnson I (1993) Birth weight from pregnancies dated by ultrasonography in a multicultural British population. BMJ 307: 588-591

26. International statistical classification of diseases and related health problems (ICD-10) 10th revision (1992) World Health Organisation, Geneva

27. British National Formulary (1993) British Medical Association

28. Stata Corp (1997) Stata Statistical Software: Release 5.0. Stata Corporation College Station, TX

29. Dahlquist G, Bennich SS, Kallen B (1996) Intrauterine growth pattern and risk of childhood onset insulin dependent (type 1) diabetes: population based case-control study. BMJ 313: 1174-1177

30. Patterson CC, Carson DJ, Hadden DR (1996) Epidemiology of childhood IDDM in Northern Ireland 1989-1994: low incidence in areas with highest population density and most household overcrowding. Diabetologia 39: 1063-1069

31. Staines A, Bodansky HJ, McKinney PA et al. (1997) Small area variation in the incidence of childhood incidence dependent diabetes mellitus in Yorkshire, UK: links with overcrowding and population density. Int $\mathbf{J}$ Epidemiol (in press)

32. Akelin-Sel T, Campbell S (1994) Intrauterine growth retardation and the role of limb reflex in circulatory redistribution. In: van Geijn HP, Copray FJA (eds) A critical appraisal of fetal surveillance. Elsevier Science BV, pp 493-501 